Geosistemy perehodnykh zon = Geosystems of Transition Zones / Геосистемы переходных зон

Content is available under the Creative Commons Attribution 4.0 International License (CC BY 4.0)

2020, vol. 4, No. 4, pp. 514-525

URL: http://journal.imgg.ru/archive.htm ; https://elibrary.ru/title about.asp?id=64191

https://doi.org/10.30730/gtrz.2020.4.4.514-525

\title{
Thermal fields of the Ebeko volcano (Paramushir Island, Kuril Islands) and their recreational and tourist potential
}

\author{
Rafael V. Zharkov \\ Institute of Marine Geology and Geophysics, FEB RAS, Yuzhno-Sakhalinsk, Russia \\ *E-mail: rafael_zharkov@mail.ru
}

\section{Abstract PDF ENG Резюме PDF RUS $\quad$ Full text $\underline{\text { PDF RUS }}$}

Abstract. The paper provides with the research results of physicochemical and balneological properties of thermal waters and hydrothermal mud of the Ebeko volcano (Paramushir Island, Kuril Islands). To assess recreational and tourist potential, we sample the most intensive thermal waters outputs. Ultra-acidic spring no. 1 of the VerkhneYuryeva group has a temperature of $88^{\circ} \mathrm{C}$, its mineralized $(\mathrm{M}-13 \mathrm{~g} / \mathrm{l})$ chloride-sulfate waters contain biologically active elements in elevated concentrations $\left(\mathrm{Si}, \mathrm{B}, \mathrm{Br}, \mathrm{Fe}^{2+}\right)$. Thermal waters of the Verkhne-Yuryeva springs can be roughly attributed to the Gaisky type of the acid water group and recommended for external use in the treatment and prevention of a wide range of diseases. Given the complexity of the route to the springs, the real development of this territory is considered not as a balneotherapy complex, but as an object of recreational and tourist activities. A similar situation is with an ultra-acidic sulfate thermal spring in the North-Eastern solfataric field. In addition to hydrotherms, it contains thin deposits of hydrothermal mud, which is almost impossible to use as a therapeutic due to its insufficiently good physical indicators and relatively small volume. The most promising deep hydrotherms for recreation and balneotherapy are opened by a well P-2 in the area of Severo-Kurilsk. In 2014, the hydrotherms temperature was $82^{\circ} \mathrm{C}$, mineralized water $(\mathrm{M}-8.6 \mathrm{~g} / \mathrm{l})$ chloride-hydrocarbonate sodium, slightly alkaline $(\mathrm{pH} 7.6)$, with an elevated content of biologically active components ( $\mathrm{Si}, \mathrm{B}, \mathrm{Br}$ ). According to the physical and chemical properties, the thermal waters of well P-2 can be tentatively attributed to the Lazarevsky hydrochemical type of therapeutic drinking water of chloride-hydrocarbonate sodium group, and as an external (balneological) use, they are tentatively close to the Kuldur type of siliceous thermal waters of various ion composition.

\section{Keywords:}

\section{Paramushir Island, Ebeko volcano, thermal waters, hydrothermal mud, balneology, recreation, tourism остров Парамушир, вулкан Эбеко, термальные воды, гидротермальные грязи, бальнеология, рекреация, туризм}

For citation: Zharkov R.V. Thermal fields of the Ebeko volcano (Paramushir Island, Kuril Islands) and their recreational and tourist potential. Geosistemy perehodnykh zon = Geosystems of Transition Zones, 2020, vol. 4, no. 4, pp. 514-525. (In Russ., abstr. in Engl.). https://doi.org/10.30730/gtrz.2020.4.4.514-525

Для цитирования: Жарков Р.В. Термопроявления вулкана Эбеко (о. Парамушир, Курильские острова) и их рекреационно-туристский потенциал. Геосистемы переходных зон, 2020, т. 4, № 4, с. 514-525.

https://doi.org/10.30730/gtrz.2020.4.4.514-525

\section{References}

1. Belousov V.I., Rychagov S.N., Sugrobov V.M. 2002. [Northern Paramushir hydrothermal and magmatic convective system: geological structure, conceptual model, geothermal resources]. Volcanology and Seismology, 1: 34-50. (In Russ.).

2. Bortnikova S.B., Bessonova E.P., Trofimova L.B. Kotenko T.A., Nikolaeva I.V. 2006. Hydrogeochemistry of thermal springs on Ebeko volcano, Paramushir Isl. J. of Volcanology and Seismology, 1: 39-51. (In Russ.).

3. Gazogidrotermy aktivnykh vulkanov Kamchatki i Kuril'skikh ostrovov: sostav, stroenie, genesis [Gas-hydrotherms of active volcanoes of Kanchatka and the Kuril Islands: composition, structure, genesis]. 2013. Authors: Bortnikova S.B., Bessonova E.P., Gora M.P., Shevko A.Ya., Panin G.L., Zharkov R.V., El'tsov I.N., Kotenko T.A., Bortnikova S.P., Manshteyn Yu.A. et al. Novosibirsk: INGG SO RAN, 282 p. (In Russ.).

4. Golubeva E.I., Zavadskaya A.V. 2012. Prospects of sustainable ecotourism development in protected areas of the Kamchatka Region. Vestnik Natsional'noy akademii turizma [Vestnik of the National tourism academy], 4(24): 43-47. (In Russ.).

5. Gorshkov G.S. 1967. Vulkany Kuril'skoy ostrovnoy dugi [Volcanoes of the Kuril island arc]. Moscow: Nauka, $287 \mathrm{p}$.

6. Degterev A.V., Chibisova M.V. 2020. The volcanic activity at the Kuril Islands in 2019. Geosistemy perehodnykh zon = Geosystems of Transition Zones, 4(1): 93-102. (In Russ.). https://doi.org/10.30730/2541-8912.2020.4.1.093-102

7. Zavadskaya A.V., Golubeva E.I. 2013. Natural complexes of hydrothermal systems of Kamchatka as objects for recreation and tourism. Geography and Natural Resources, 34(4): 339-344. 
8. Zavadskaya A.V., Yablokov V.M. 2014. [Ecological and geographical basis for recreational usage of thermal ecosystems (on the example of the valley of the Geyzernaya river)]. In.: Trudy Kronotskogo gosudarstvennogo prirodnogo biosfernogo zapovednika [Proceedings of the Kronotsky state nature biosphere reserve], Voronezh: STP, 190-208. (In Russ.).

9. Zelenov K.K., Tkachenko R.P., Kanakina M.L. 1965. [Redistribution of the ore-forming elements during hydrothermal activity of the Ebeco volcano (Paramushir Island)]. Trudy GIN AN SSSR [Proceedings of Geological Institute of the USSR Academy of Sciences], 141: 140-167. (In Russ.).

10. Ivanov V.V. 1957. [Modern hydrothermal activity of the Ebeco volcano on Paramushir Island]. Geokhimiya [Geochemistry], 1: 63-77. (In Russ.).

11. Kalacheva E.G., Kotenko T.A. 2013. Water geochemistry and formation conditions of the Verkhne-Yuryeva thermal springs, Paramushir Island. Vestnik KRAUNTs. Nauki o Zemle = Bull. of KRAESC. Earth Sciences, 22(2): 55-68. (In Russ.).

12. Kalacheva E.G., Taran Yu.A. 2019. Processes controling isotopic composition ( $\delta \mathrm{D}$ and $\left.\delta^{18} \mathrm{O}\right)$ of thermal waters of the Kuril Island Arc. J. of Volcanology and Seismology, 13(4): 201-215. https://doi.org/10.1134/s0742046319040031

13. Kotenko T.A., Kotenko L.V. 2006. The hydrothermal manifestations and heat flow by Ebeko and Krasheninnikov volcanoes (Paramushir Isl., Kuril islands). Vestnik KRAUNTs. Nauki o Zemle = Bull. of KRAESC. Earth Sciences, 1(7): $129-137$. (In Russ.).

14. Kotenko T.A., Kotenko L.V., Shapar' V.N. 2007. Increased activity on Ebeko volcano, Paramushir I., North Kuriles in 20052006. J. of Volcanology and Seismology, 1(5): 285-295. https://doi.org/10.1134/s0742046307050016

15. Kotenko T.A., Sandimirova E.I., Kotenko L.V. 2018. The 2016-2017 eruptions of Ebeko volcano (Kuriles Islands). Vestnik KRAUNTs. Nauki o Zemle = Bull. of KRAESC. Earth Sciences, 1(37): 32-42. (In Russ.).

16. Markhinin E.K., Stratula D.S. 1977. Gidrotermy Kuril'skikh ostrovov [Hydrotherms of the Kuril Islands]. Moscow: Nauka, $212 \mathrm{p}$.

17. Melekestsev I.V., Dvigalo V.N., Kir'yanov V.Yu., Kurbatov A.V., Nesmachnyy I.A. 1993a. [The Ebeco volcano (the Kuril Islands): history of eruptive activity and future volcanic hazard. Part 1]. Volcanology and Seismology, 3: 69-81. (In Russ.).

18. Melekestsev I.V., Dvigalo V.N., Kir'yanov V.Yu., Kurbatov A.V., Nesmachnyy I.A. 1993b. [The Ebeco volcano (the Kuril Islands): history of eruptive activity and future volcanic hazard. Part 2]. Volcanology and Seismology, 4: 24-41. (In Russ.).

19. Menyaylov I.A., Nikitina L.P., Shapar' V.N. 1988. [Features of chemical and isotopic composition of fumarole gases during the repose period of the Ebeco volcano activity]. Volcanology and Seismology, 4: 21-36. (In Russ.).

20. Menyaylov I.A., Nikitina L.P., Budnikov V.A. 1992. [The Ebeco volcano activity during 1987-1991: eruptions character, features of their products, hazard for the town of Severo-Kurilsk]. Volcanology and Seismology, 5-6: 21-33. (In Russ.).

21. Nekhoroshev A.S. 1960. [Geothermal conditions and heat flow of the Ebeco volcano on Paramushir Island]. Byul. vulkanologicheskikh stantsii [Bulletin of volcanological station], 29: 38-46. (In Russ.).

22. Panin G.L., Kotenko T.A., Kotenko L.V., Karin U.G. 2010. Geophysical and geochemical investigations of thermal fields of Ebeco volcano (Paramushir Island). Litosfera = Lithosphere (Russia), 3: 171-176. (In Russ.).

23. Rybin A.V., Degterev A.V., Chibisova M.V., Gur'yanov V.B., Koroteev I.G. 2016a. Volcanic activity in the Kurile Islands in 2012-2015. Vestnik KRAUNTs. Nauki o Zemle = Bull. of KRAESC. Earth Sciences, 2(30): 77-87. (In Russ.).

24. Rybin A.V., Chibisova M.V., Degterev A.V. 2018. The 2017 activity of the Kurile Islands volcanoesa. Vestnik KRAUNTs. Nauki o Zemle = Bull. of KRAESC. Earth Sciences, 2(38): 102-109. (In Russ.). doi:10.31431/1816-5524-2018-2-38-102-109

25. Rychagov S.N., Pushkarev V.G., Belousov V.I., Kuz'min D.Yu., Mushinskiy A.V., Sandimirova E.I., Boykova I.A., Shul'ga O.V., Nikolaeva A.G., Egorova N.P. 2004. North Kuril geothermal field: geologic structure and development potential. J. of Volcanology and Seismology, 2: 56-72. (In Russ.).

26. Firstov P.P., Kotenko T.A., Akbashev R.R. 2020. Growth of explosive activity of Ebeko volcano in April-June 2020. Vestnik KRAUNTs. Nauki o Zemle = Bull. of KRAESC. Earth Sciences, 2(46): 10-15. (In Russ.). https://doi.org/10.31431/1816-5524-20202-46-10-15

27. Chelnokova B.I., Gvozdenko T.A. 2017. Mineral'nye vody i lechebnye gryazi Dal'nego Vostoka [Mineral waters and therapeutic mud of the Far East]. Vladivostok: DVFU, 220 p. (In Russ.).

28. Chudaev O.V. 2003. Sostav i usloviya obrazovaniya sovremennykh gidrotermal'nykh sistem Dal'nego Vostoka Rossii [Composition and formation conditions of the modern hydrothermal systems of the Russian Far East]. Vladivostok: Dal'nauka, 216 p. (In Russ.).

29. Chudaev O., Chudaeva V., Sugimory K., Kuno A., Matsuo M., Nordstrom K. 2006. Geochemistry of hydrothermal system of Kuril Islands. In: Proceedings of $5^{\text {th }}$ Biennial Workshop on Subduction Processes emphasizing the Japan-Kuril-KamchatkaAleutian Arcs. Hokkaido University, 1-5. (In Russ.).

30. Kalacheva E., Taran Yu. 2018. Role of hydrothermal flux in the volatile budget of a subduction zone: Kuril arc, northwest Pacific. Geology. https://doi.org/10.1130/G45559.1

31. Kalacheva E., Taran Yu., Kotenko T., Hattori K., Kotenko L., Solis-Pichardo G. 2016. Volcano-hydrothermal system of Ebeko volcano, Paramushir, Kuril Islands: Geochemistry and solute fluxes of magmatic chlorine and sulfur. J. of Volcanology and Geothermal Research: 118-131. https://doi.org/10.1016/j.jvolgeores.2015.11.006

32. Taran Y., Zelenski M., Chaplygin I., Malik N., Campion R., Inguaggiato S., Pokrovsky B., Kalacheva E., Melnikov D., Kazahaya R., Fischer T. 2018. Gas emissions from volcanoes of the Kuril Island arc (NW Pacific): Geochemistry and fluxes. In: Geochemistry Geophysics Geosystems, vol. 19: 1859-1880. https://doi .org/10.1029 /2018GC007477 